Jurnal Sastra Indonesia

\title{
Analisis Fitur Kebahasaan Teks Tajuk Rencana Harian Suara Merdeka dan Kompas Edisi 1 sampai dengan 30 April 2017
}

\author{
Desy Hastuti ${ }^{\bowtie}$, Bambang Hartono, Santi Pratiwi Tri Utami \\ Jurusan Bahasa dan Sastra Indonesia, Fakultas Bahasa dan Seni, Universitas Negeri Semarang, \\ Indonesia
}

\begin{tabular}{|c|c|}
\hline Info Artikel & Abstrak \\
\hline $\begin{array}{l}\text { Sejarah Artikel: } \\
\text { Diterima Desember } 2018 \\
\text { Disetujui Mei } 2019 \\
\text { Dipublikasikan Juli } 2019\end{array}$ & $\begin{array}{l}\text { Penelitian ini bertujuan untuk mengidentifikasi perbedaan karakteristik fitur kebahasaan yang } \\
\text { terdapat pada wacana teks Tajuk Rencana Harian Suara Merdeka dan Kompas Edisi } 1 \text { sampai } \\
\text { dengan } 30 \text { April } 2017 \text {. Pendekatan yang digunakan dalam penelitian ini adalah pendekatan teoretis } \\
\text { dan pendekatan metodologis. Pendekatan teoretis dalam penelitian ini menggunakan pendekatan } \\
\text { analisis wacana, sedangkan pendekatan metodologis yang digunakan berupa pendekatan kualitatif }\end{array}$ \\
\hline $\begin{array}{l}\text { Kata kunci: } \\
\text { pronomina petunjuk; } \\
\text { konjungsi kausalitas; } \\
\text { konjungsi pertentangan; } \\
\text { konjungsi misalan. }\end{array}$ & $\begin{array}{l}\text { yang bersifat deskriptif. Data dalam penelitian ini berupa penggalan wacana yang terdapat dalam } \\
\text { teks Tajuk Rencana Harian Suara Merdeka dan Kompas Edisi } 1 \text { sampai dengan } 30 \text { April } 2017 \text {. } \\
\text { Metode pengumpulan data yang digunakan adalah metode simak yang dilanjutkan dengan teknik } \\
\text { catat. Metode analisis data yang digunakan dalam penelitian ini adalah metode agih yang } \\
\text { dilanjutkan dengan teknik baca markah. Metode penyajian hasil analisis data yang digunakan } \\
\text { adalah metode penyajian informal. Berdasarkan hasil penelitian, ditemukan } 91 \text { data untuk } \\
\text { penggunaan pronomina penunjuk, } 69 \text { data untuk penggunaan konjungsi kausalitas, } 81 \text { data untuk }\end{array}$ \\
\hline Keywc & jungsi pertentangan, dan 5 data untuk konjungsi misalan. \\
\hline
\end{tabular}

pronouns pointer;

conjunction causalit;

conjunction contradiction;

conjunction for example.

\begin{abstract}
This study aims to identify differences in characteristics of linguistic features contained in the text discourse of the Daily Plans of Suara Merdeka and Kompas Edition 1 to April 30, 2017. The approach used in this study is theoretical approach and methodological approach. The theoretical approach in this research uses discourse analysis approach, while the methodological approach used is descriptive qualitative approach. The data in this study is a fragment of discourse contained in the text of the Daily Suara Merdeka and Kompas Edition 1 to April 30, 2017. The data collection method used is the refer method followed by the record technique. Data analysis methods used in this study is a method that continued with the technique of reading markah. Method of presentation of result of data analysis used is method of informal presentation. Based on the results of the study, 91 data were found for the use of pronominal pointers, 69 data for the use of conjunction causality, 81 data for conjunction contradictions, and 5 data for conjunctions.
\end{abstract}

(C) 2019 Universitas Negeri Semarang

$\begin{array}{ll}\text { × Alamat korespondensi: } & \text { P-ISSN 2252-6315 } \\ \text { Gedung B1 Lantai 1 FBS Unnes } & \text { E-ISSN 2685-9599 } \\ \text { Kampus Sekaran, Gunungpati, Semarang, 50229 } & \\ \text { E-mail: hastutidesy@gmail.com } & \end{array}$




\section{PENDAHULUAN}

Wacana merupakan tataran yang paling besar dalam hierarki kebahasaan. Sebagai tataran terbesar dalam hierarki kebahasaan, wacana tidak merupakan susunan kalimat secara acak, tetapi merupakan satuan bahasa, baik lisan maupun tertulis. Untuk wacana yang disampaikan secara tertulis ini dimaksudkan agar tulisan tersebut dapat dipahami dan diinterpretasikan oleh pembaca.

Informasi yang disampaikan melalui tulis tentu mempunyai perbedaan dengan informasi yang disampaikan secara lisan. Perbedaan itu ditandai oleh adanya keterkaitan antarproposisi. Keterkaitan antara wacana tulis dinyatakan secara eksplisit yang merupakan rangkaian antar kalimat secara gramatikal. Adapun untuk bahasa lisan keterkaitan itu dinyatakan secara implisit, di mana kejelasan informasi akan didukung oleh konteks.

Berdasarkan pernyataan di atas dapat dikatakan bahwa bahasa lisan atau ujaran lebih ditekankan pada konteks dan situasi untuk lebih menjelaskan topik pembicaraan pada saat komunikasi. Lain halnya pada bahasa tulis, keterkaitan kalimat sebagai unsur pembangun wacana, harus dirangkaikan secara runtut sehingga menjadi wacana yang mempunyai kepaduan. Kelompok kata belum tentu disebut wacana bila rentetan itu tidak memberikan informasi yang lengkap unsur-unsur yang membangun wacana. Di dalam wacana tulis terjadi komunikasi secara tidak langsung antara penulis dengan pembaca.

Yang termasuk dalam wacana tulis salah satunya dapat dijumpai dalam bentuk media massa. Media cetak merupakan salah satu media massa yang termasuk wacana bentuk tulis. Salah satu media cetak yang paling produktif menggunakan wacana bentuk tulis adalah tajuk rencana yang terdapat dalam surat kabar.

Tajuk rencana memiliki kedudukan yang sangat penting karena beberapa faktor. Faktor pertama, setiap harian pasti mempunyai tajuk rencana yang mengkaji masalah yang hangat dibicarakan di masyarakat. Faktor kedua, tajuk rencana mengkaji merupakan pandangan redaktur yang mewakili sebuah harian terhadap permasalahan yang sedang dibicarakan di masyarakat. Faktor ketiga, tajuk rencana memberikan pemahaman atas suatu permasalahan.

Gaya bahasa dalam tajuk rencana harus sedemikian rupa, sehingga mudah dipahami dan menitikberatkan pada kejelasan dan ketepatan makna, karena tidak semata-mata ditujukan pada keindahan bahasa. Tujuannya adalah supaya pembaca dapat dipengaruhi dengan segera dan dapat diyakinkan dengan tepat, maka gaya atau karakteristik kebahasaan yang digunakan harus sesuai dengan tujuan yang dimaksud.

Dalam bukunya "Jenis-Jenis Teks", Kosasih (2014) mengemukakan kaidah atau karakteristik kebahasaan yang terdapat pada tajuk rencana meliputi: (a) adanya penggunaan ungkapan-ungkapan retoris; (b) banyak menggunakan kata-kata populer; (c) banyak menggunakan kata ganti tunjuk yang merujuk pada waktu, tempat, peristiwa, atau hal lainnya yang menjadi fokus ulasan; (d) banyak penggunaan konjungsi atau kata sambung kausalitas (sebab-akibat); dan (e) banyaknya penggunaan konjungsi pertentangan, seperti akan tetapi, namun. Sependapat dengan Anderson dalam bukunya Text Types (2003:128) dalam teks editorial atau teks tajuk rencana terdapat karakteristik kebahasaan yang meliputi, (1) Mengungkapkan sudut pandang dengan jelas, (2) menggunakan alasan untuk mendukung gagasan, (3) menggunakan gagasan atau alasan untuk mendukung argumen tersebut, (4) menggunakan bukti untuk membuktikan gagasan atau alasan yang mendukung, dan (5) menunjukkan sebab dan akibat. Pada penelitian ini peneliti tertarik untuk melakukan penelitian pada wacana tulis, yaitu pada wacana teks Tajuk Rencana Harian Suara Merdeka dan Kompas Edisi 1 sampai dengan 30 April 2017. Peneliti akan membahas aspek fitur kebahasaan pada wacana teks kolom Tajuk Rencana Harian Suara Merdeka dan Kompas Edisi 1 sampai dengan 30 April 2017. Fitur kebahasaan adalah karakteristik khusus yang terdapat pada suatu atau perihal bahasa seperti layaknya sebuah bagan atau kerangka kerja yang disusun dan membuat struktur 
kebahasaan dan atau jenis teks yang benar. Dalam penelitian ini fitur kebahasaan merupakan suatu karakteristik kebahasaan yang dimiliki oleh tajuk rencana. Fitur kebahasaan yang akan diteliti mengenai perbedaan karakteristik kebahasaan yang terdapat pada Tajuk Rencana Harian Suara Merdeka dan Kompas Edisi 1 sampai dengan 30 April 2017.

Peneliti menggunakan tajuk rencana harian Suara Merdeka sebagai harian nasional yang khusus daerah khususnya Jawa Tengah dan Kompas yang memiliki wilayah publikasi yang luas (nasional) sebagai pembanding. Selain itu, keduanya juga memiliki dua kolom tajuk rencana.

Penelitian ini juga terkait dengan penelitian sebelumnya, yaitu penelitian yang dilakukan Dina Etikawati (2015) yang terkait dengan kesantunan tuturan, serta penelitian Endro Nugroho Wasono Aji (2017) yang terkait dengan tajuk rencana, dan penelitian Ahmad Faulin (2018) dam Febrian Kurniaji (2018) yang terkait dengan kebahaasaan.

\section{METODE}

Pendekatan dalam penelitian ini menggunakan dua pendekatan, yaitu pendekatan secara teoretis dan pendekatan secara metodologis. Pendekatan secara teoretis dalam penelitian ini menggunakan pendekatan analisis wacana, artinya peneliti sebagai penganalisis mengkaji wacana baik dari segi internal maupun dari segi eksternal. Pendekatan selanjutnya yang digunakan peneliti adalah pendekatan metodologis Secara metodologis pendekatan dalam penelitian ini menggunakan pendekatan kualitatif yang bersifat deskriptif. Pendekatan kualitatif berkaitan dengan data yang tidak berupa angka-angka, tetapi penggunaan bentukbentuk bahasa dan pendekatan deskriptif berkaitan dengan penjabaran mengenai data yang diperoleh. Moleong (2009:11) berpendapat bahwa data penelitian deksriptif kualitatif berupa kata-kata, gambar, dan bukan angka-angka. Dengan demikian, laporan penelitian akan berisi kutipan-kutipan data untuk memberi gambaran penyajian laporan tersebut.
Data dalam penelitian ini berupa penggalan wacana yang terdapat pada teks Tajuk Rencana Harian Suara Merdeka dan Kompas Edisi 1 sampai dengan 30 April 2017. Sumber data dalam penelitian ini berupa teks Tajuk Rencana Harian Suara Merdeka dan Kompas Edisi 1 sampai dengan 30 April 2017.

Metode pengumpulan data yang digunakan dalam penelitian ini adalah metode simak dengan teknik catat. Metode penyediaan data ini disebut metode simak karena cara yang digunakan untuk memperoleh data dilakukan dengan menyimak penggunaan bahasa (Mahsun 2014). Setelah metode simak dilakukan, langkah selanjutnya adalah pencatatan. Teknik catat adalah teknik menjaring atau dengan mencatat hasil penyimakan data pada kartu data (Kesuma 2007:45). Teknik pencatatan dalam penelitian ini dilakukan dengan mencatat peggalan wacana yang ada di dalam teks Tajuk Rencana Harian Suara Merdeka dan Kompas Edisi 1 sampai dengan 30 April 2017 yang diduga terdapat fitur kebahasaan.

Metode analisis data yang digunakan dalam penelitian ini menggunakan metode agih. Metode agih disebut juga metode distribusional (Sudaryanto dalam Kesuma 2007:54) adalah metode analisis yang alat penentunya ada di dalam dan merupakan bagian dari bahasa yang diteliti. Metode agih dilanjutkan dengan teknik baca markah. Teknik baca markah menurut Sudaryanto (2015:129) disebut juga teknik membaca pemarkah. Pemarkah itu adalah alat, seperti imbuhan, kata penghubung, kata depan, dan artikel yang menyatakan ciri ketatabahasaan atau fungsi kata atau kontruksi (Kridalaksana dalam Kesuma 2007:66). Teknik ini digunakan untuk meganalisis data penelitian, yaitu mendeskripsikan pronomina penunjuk, konjungsi sebab-akibat, konjungsi kontrastif, dan konjungsi misalan yang ada dalam teks Tajuk Rencana Harian Suara Merdeka dan Kompas Edisi 1 sampai dengan 30 April 2017. Metode penyajian hasil analisis data dalam penelitian ini menggunakan metode informal. 


\section{HASIL DAN PEMBAHASAN}

Berdasarkan rumusan masalah dan tujuan penelitian, dikemukakan hasil penelitian dan pembahasan tentang fitur kebahasaan teks tajuk rencana harian Suara Merdeka, fitur kebahasaan teks tajuk rencana harian Kompas, dan perbedaan jumlah persentase. Hasil analisisnya adalah (1) fitur kebahasaan yang terdapat pada Tajuk Rencana Harian Suara Merdeka Edisi 1 sampai dengan 30 April 2017, (2) fitur kebahasaan yang terdapat pada Tajuk Rencana Harian Kompas Edisi 1 sampai dengan 30 April 2017, dan (3) perbedaan jumlah persentase karakteristik fitur kebahasaan Tajuk Rencana antara Harian Suara Merdeka dan Kompas Edisi 1 sampai dengan 30 April 2017.

Fitur Kebahasaan Teks Tajuk Rencana Harian Suara Merdeka Edisi 1 sampai dengan 30 April 2017

Fitur kebahasaan yang ditemukan dalam Tajuk Rencana Harian Suara Merdeka edisi 1 30 April 2017 meliputi penggunaan pronomina penunjuk sebanyak 91 data, konjungsi kausalitas sebanyak 69 data, konjungsi pertentangan sebanyak 81 data, dan konjungsi misalan sebanyak 5 data.

\section{Pronomina Penunjuk}

Pronomina penunjuk dalam bahasa Indonesia ada tiga macam, yaitu (1) pronomina penunjuk umum, (2) pronomina penunjuk tempat, dan (3) pronomina penunjuk ihwal (Alwi et. al. 2003:260). Dalam penelitian ini pronomina penunjuk umum ditemukan sebanyak 76 data, pronomina penunjuk tempat ditemukan sebanyak 2 data, dan pronomina penunjuk ihwal ditemukan sebanyak 13 data.

Pronomina Penunjuk Umum

Pronomina penunjuk umum ditandai dengan kata ini, itu. Kata ini mengacu pada acuan yang dekat dengan pembicara/penulis, pada masa yang akan datang, atau pada informasi yang akan disampaikan. Untuk acuan pada yang agak jauh dari pembicara/penulis, pada masa lampau, atau pada informasi yang sudah di sampaikan, digunakan kata itu (Alwi et. al. dalam Hartono, 2012:111). Terdapat pronomina penunjuk umum yang ditandai dengan kata ini sebanyak 28 data dan pronomina penunjuk umum yang ditandai dengan kata itu sebanyak 48 data.

Kejadian itu tentu memunculkan duka mendalam bagi lingkungan sekolah yang mengadopsi pendidikan ala militer tersebut. Namun, baru kali ini terjadi kejadian tragis pada SMA sejak sekolah di Magelang ini berdiri pada 1990.

(Data 80/P1/0304/SM1)

Peggalan wacana tersebut terdapat pronomina penunjuk umum yang ditandai dengan kata ini yang menempatkan acuan dekat dengan penulis.

Untuk kali keenam, Satria Brand Award (SBA) diberikan kepada merek-merek yang dinilai terbaik oleh para konsumen Jawa Tengah. Acara tahunan yang diselenggarakan Suara Merdeka itu berbasiskan hasil penelitian.

(Data 166/P1/2904/SM2)

Peggalan wacana tersebut terdapat pronomina penunjuk umum yang ditandai dengan kata itu yang mengacu pada informasi yang sudah disampaikan.

Pronomina Penunjuk Tempat

Pronomina penunjuk tempat dalam bahasa Indonesia ialah sini, situ, dan sana. Titik pangkal perbedaan di antara ketiganya ada pada pembicara/penulis: dekat (sini), agak jauh (situ), dan jauh (sana). Karena menunjuk lokasi, pronomina ini sering digunakan dengan preposisi pengacu arah, di/ke/dari, sehingga terdapat di/ke/dari sini, di/ke/dari situ, dan di/ke/dari sana (Alwi et. al. dalam Hartono, 2012:111). Terdapat pronomina penunjuk tempat yang ditandai dengan kata sini sebanyak 1 data dan pronomina penunjuk tempat yang ditandai dengan kata sana sebanyak 1 data. Sedangkan pronomina penunjuk tempat yang ditandai dengan kata situ tidak ditemukan.

Semua diserahkan kepada profesionalisme penegak hukum terlebih KPK yang mempunyai reputasi bagus. Justru di sinilah terlihat adanya niat yang patut dipertanyakan karena arahnya 
seperti menuju pada upaya menghambat proses hukum, sampai-sampai hak angket digunakan.

(Data 161/P4/2804/SM1)

Pada penggalan wacana tersebut terdapat pronomina penunjuk tempat yang ditandai dengan kata sini yang menunjuk sesuatu yang dekat atau di tempat penulis.

Benarkah kasus itu sudah diusut sampai tuntas dan tidak ada hakim lain yang terlibat? Lalu apa daya seorang Saldi Isra kalau ternyata mafia peradilan sudah ada di sana.

(Data 117/P3/1204/SM1)

Pada penggalan wacana tersebut terdapat pronomina penunjuk tempat yang ditandai dengan kata sana yang menunjuk sesuatu yang tempatnya jauh dari penulis.

Pronomina Penunjuk Ihwal

Pronomina penunjuk ihwal dalam bahasa Indonesia ialah begini, begitu, dan demikian. Pronomina penunjuk begini menunjuk sesuatu yang letaknya dekat dengan pembicara atau penulis. Pronomina penunjuk begitu menunjuk sesuatu yang letaknya jauh dari pembicara atau penulis. Sedangkan pronomina penunjuk demikian dapat digunakan untuk menggantikan pronomina penunjuk begini dan begitu (Hartono, 2012:128). Terdapat pronomina penunjuk ihwal yang ditandai dengan kata begitu sebanyak 5 data dan pronomina penunjuk ihwal yang ditandai dengan kata demikian sebanyak 8 data. Sedangkan penunjuk ihwal yang ditandai dengan kata begini tidak ditemukan.

Harapannya, pelayanan kepada masyarakat selalu dalam kondisi yang paling prima. Dengan begitu, keberadaan BRT benarbenar menjadi kebutuhan.

(Data 93/P5/0404/SM2)

Pada penggalan wacana tersebut terdapat pronomina penunjuk ihwal yang ditandai dengan kata begitu yang menunjuk sesuatu yang letaknya jauh dari penulis.

\section{Konjungsi Kausalitas}

Konjungsi kausalitas terdiri atas konjungsi akibatan, konjungsi alahan, konjungsi eksesif, dan konjungsi sebaban. Konjungsi sebab akibat yang digunakan sebagai pemarkah kohesi adalah sebab itu, karena itu untuk konjungsi akibatan; walaupun demikian, biarpun begitu untuk konjungsi alahan; sampai-sampai, malahan, bahkan untuk konjungsi eksesif; oleh sebab itu, karena, sebab untuk konjungsi sebaban (Samsuri dalam Hartono 2012:139). Terdapat konjungsi akibatan yang ditandai dengan kata karena itu sebanyak 22 data; konjungsi eksesif yang ditandai dengan kata sampai-sampai sebanyak 1 data dan bahkan sebanyak 19 data; dan konjungsi sebaban yang ditandai dengan kata sebab sebanyak 2 data dan karena sebanyak 24 data. Sedangkan konjungsi akibatan yang ditandai dengan kata sebab itu; konjungsi alahan yang ditandai dengan kata walaupun demikian, biarpun begitu; dan konjungsi eksesif yang ditandai dengan kata malahan tidak ditemukan.

Rusunawa didesain bukan saja berfungsi sebagai tempat tinggal, namun sebagai inkubator atau ruang besar yang nyaman dengan berbagai interaksi sosial di dalamnya. Karena itu, rusunawa diupayakan senantiasa dalam keadaan baik, aman ditinggali, layak fungsi, dan nyaman dihuni.

(Data 207/P5/1204/SM2)

Pada penggalan wacana tersebut terdapat konjungsi akibatan yang ditandai dengan kata karena itu yang menyatakan akibat dari kalimat sebelumnya.

Hampir setiap hari kita membaca berita adanya pengguna, pengedar, dan bandar ditangkap. Kepala Badan Nasional Narkotika Budi Waseso geram dengan peredaran itu, sampai-sampai menyatakan ingin berguru kepada Presiden Filipina Rodrigo Duterte.

(Data 183/P1/0604/SM1)

Pada penggalan wacana tersebut terdapat konjungsi eksesif yang ditandai dengan kata sampai-sampai yang menyatakan akibat yang berlebihan tentang suatu hal yang telah disebut pada kalimat sebelumnya.

Ketika CAT Watuputih nantinya ditetapkan sebagai KBAK dan terjadi penambangan, warga penerima aliran ke timur menjadi daerah terdampak. Sebab, Watuputih menjadi sumber mata air bagi warga di daerah Jawa Timur, sedangkan sumber mata air di CAT itu berasal dari Gunung Butak, bukan Watuputih. 
(Data 218/P3/1704/SM1)

Pada penggalan wacana tersebut terdapat konjungsi sebaban yang ditandai dengan kata sebab yang bermakna sama dengan konjungsi akibatan, perbedaannya terletak pada konjungsi yang digunakan.

\section{Konjungsi Pertentangan}

Konjungsi yang digunakan sebagai pemarkah kohesi adalah akan tetapi, namun, dan tetapi. Terdapat konjungsi kontrastif yang ditandai dengan kata akan tetapi sebanyak 2 data, namun sebanyak 44 data, dan tetapi sebanyak 35 data.

Perempuan-perempuan masa kini, dari kalangan mana pun, senantiasa menjadikan Kartini sebagai teladan kehidupan. Akan tetapi bisa dipastikan mereka lebih memahami Sang Putri Jepara itu sebagai tokoh emansipasi wanita daripada juru kritik bagi feodalisme, keegoistisan, kapitalisme, praktik-praktik diskriminatif, dan penundukan dan perbudakan kaum perempuan.

(Data 319/P1/2204/SM1)

Untuk pemerataan ekonomi, ditargetkan penyerahan lima juta sertifikat tanah kepada kelompok ekonomi lemah pada tahun ini. Namun Kementerian ATR hanya mampu membagikan 400 ribu sertifikat.

(Data 326/P2/2504/SM2)

Salah satu alasannya merawat konstituen di daerah untuk mendulang suara. Tetapi, perlu diingat mereka memperoleh fasilitas berupa gaji, tunjangan, dan banyak lainnya karena bekerja sebagai anggota Dewan.

(Data 310/1904/SM2)

Pada tiga penggalan wacana tersebut terdapat konjungsi kontrastif yang ditandai dengan kata akan tetapi, namun, dan tetapi yang menyatakan hubungan ketidaksesuaian apa yang disampaikan kalimat sebelumnya.

\section{Konjungsi Misalan}

Konjungsi yang digunakan untuk memarkahi hubungan kohesi adalah misal, misalnya, dan umpamanya. Terdapat konjungsi misalan yang ditandai dengan kata misal sebanyak 3 data dan konjungsi misalan yang ditandai dengan kata misalnya sebanyak 2 data.
Sedangkan konjungsi misalan yang ditandai dengan kata umpamanya tidak ditemukan.

Menempatkan pedagang dan perdagangan komoditi sejenis akan memudahkan orang-orang untuk langsung menuju pasar yang sesuai dengan kebutuhan mereka. Misal sekarang ini jika orang butuh membeli tanaman atau bunga, mereka akan langsung ke Pasar Kembang Kalisari.

(Data 394/P4/1804/SM2)

Diperlukan terobosan dan penataan hukum untuk menepis anggapan minor tersebut, misalnya adanya aturan penguatan peran Bawaslu sebagai lembaga yang dapat menghapus peraturan KPU yang dianggap bertentangan dengan undang-undang.

(Data 392/P6/0804/SM2)

Pada kedua penggalan wacana tersebut terdapat konjungsi misalan yang ditandai dengan kata misal dan misalnya yang menyebutkan contoh-contoh tentang sesuatu hal yang telah disebutkan pada kalimat sebelumnya.

Fitur Kebahasaan Teks Tajuk Rencana Harian Kompas Edisi 1 sampai dengan 30 April 2017

Fitur kebahasaan yang ditemukan dalam Tajuk Rencana Harian Kompas edisi 1 sampai dengan 30 April 2017 meliputi, penggunaan pronomina penunjuk sebanyak 75 data, konjungsi kausalitas sebanyak 17 data, konjungsi pertentangan sebanyak 54 data, dan konjungsi misalan sebanyak 6 data. Berikut analisisnya.

\section{Pronomina Penunjuk}

Pronomina penunjuk dalam bahasa Indonesia ada tiga macam, yaitu (1) pronomina penunjuk umum, (2) pronomina penunjuk tempat, dan (3) pronomina penunjuk ihwal (Alwi et. al. 2003:260). Dalam penelitian ini pronomina penunjuk umum ditemukan sebanyak 66 data, pronomina penunjuk tempat ditemukan sebanyak 1 data, dan pronomina penunjuk ihwal ditemukan sebanyak 8 data.

Pronomina Penunjuk Umum

Pronomina penunjuk umum ditandai dengan kata ini, itu. Dari 400 data terdapat pronomina penunjuk umum yang ditandai dengan kata ini sebanyak 39 data dan pronomina 
penunjuk umum yang ditandai dengan kata itu sebanyak 27 data.

Badan Geologi Kementerian Energi dan Sumber Daya Mineral bahkan telah memetakan kawasan rawan longsor lengkap dengan skala kerentanannya. Peta ini, dipadukan dengan prakiraan curah hujan dan bentang alam, menghasilkan peta potensi gerakan tanah yang diperbarui setiap bulan.

(Data 13/P4/0604/KM1)

Pada penggalan wacana di atas terdapat pronomina penunjuk umum yang ditandai dengan kata ini mengacu pada pronomina penunjuk yang menempatkan acuan dekat dengan penulis.

Selasa pagi, Novel disiram air keras oleh orang tak dikenal. Kabar itu dengan cepat tersiar.

(Data 31/1204/KM1)

Pada penggalan wacana di atas terdapat pronomina penunjuk umum yang ditandai dengan kata itu yang menyatakan informasi yang sudah disampaikan pada kalimat sebelumnya.

Pronomina Penunjuk Tempat

Pronomina penunjuk tempat dalam bahasa Indonesia ialah sini, situ, dan sana. Dari 400 data terdapat pronomina penunjuk tempat yang ditandai dengan kata sini sebanyak 1 data. Sedangkan pronomina penunjuk tempat yang ditandai dengan kata sana dan situ tidak ditemukan.

Menjadikan koperasi/UMKM sebagai mitra sejajar usaha besar menjadi penting di sini mengingat sebagai salah satu soko guru penting ekonomi, koperasi dewasa ini ibarat hidup enggan mati tak mau, sementara UMKM masih banyak terkendala dalam akses pembiayaan, pemasaran, teknologi, dan lain-lain. Padahal, di koperasi/UMKM-lah ekonomi mayoritas masyarakat, khususnya bawah, bertumpu.

(Data 66/P6/2604/KM1)

Pada penggalan wacana di atas terdapat pronomina penunjuk tempat yang ditandai dengan kata sini mengacu pada pronomina penunjuk yang menunjuk sesuatu yang tempatnya dekat penulis.

Pronomina Penunjuk Ihwal

Pronomina penunjuk ihwal dalam bahasa Indonesia ialah begini, begitu, dan demikian.
Dari 400 data terdapat pronomina penunjuk ihwal yang ditandai dengan kata begitu sebanyak 1 data dan kata demikian sebanyak 7 data. Sedangkan penunjuk ihwal yang ditandai dengan kata begini tidak ditemukan.

Harga suatu barang terbentuk karena permintaan dan penawaran, kenaikan pasokan segera berdampak turunnya harga. Meski begitu, pasar tidak selalu sempurna. Bisa jadi karena ada yang menahan stok.

(Data 20/P6/0704/KM2)

Pada penggalan wacana di atas terdapat pronomina penunjuk ihwal yang ditandai dengan kata begini mengacu pada pronomina penunjuk yang menyatakan informasi yang sudah disampaikan pada kalimat sebelumnya.

Sebaliknya, berangkat dari realitas seperti itu, Indonesia harus memainkan peran lebih aktif untuk mewujudkan perdamaian dan stabilitas sejalan dengan kepentingan-kepentingan strategisnya di kawasan. Dengan demikian, posisi dan peran Indonesia pun akan semakin mantap.

(Data 21/P8/0704/KM2)

Pada penggalan wacana di atas terdapat pronomina penunjuk ihwal yang ditandai dengan kata demikian mengacu pada pronomina penunjuk ihwal menggantikan pronomina penunjuk begini dan begitu.

\section{Konjungsi Kausalitas}

Konjungsi yang memiliki makna sebab akibat. Konjungsi kausalitas terdiri atas konjungsi akibatan, konjungsi alahan, konjungsi eksesif, dan konjungsi sebaban. Konjungsi sebab akibat yang digunakan sebagai pemarkah kohesi adalah sebab itu, karena itu untuk konjungsi akibatan; walaupun demikian, biarpun begitu untuk konjungsi alahan; sampai-sampai, malahan, bahkan untuk konjungsi eksesif; oleh sebab itu, karena, sebab untuk konjungsi sebaban (Samsuri dalam Hartono 2012:139). Dari 400 data terdapat konjungsi akibatan yang ditandai dengan kata karena itu sebanyak 7 data; konjungsi eksesif yang ditandai dengan kata bahkan sebanyak 6 data; dan konjungsi sebaban yang ditandai dengan kata karena sebanyak 4 data. Sedangkan konjungsi akibatan yang 
ditandai dengan kata sebab itu; konjungsi alahan yang ditandai dengan kata walaupun demikian, biarpun begitu; dan konjungsi eksesif yang ditandai dengan kata sampai-sampai dan malahan; serta konjungsi sebaban oleh sebab itu dan sebab tidak ditemukan.

Kawasan Asia Timur akan menjadi mandala pertemuan berbagai kepentingan banyak negara dan menjadi kawasan yang paling dinamis. Dan, Indonesia berada di kawasan tersebut. Karena itu, adalah masuk akal dan logis bahwa negara-negara seperti Perancis, Arab Saudi, dan juga Afganistan dalam tingkatan yang berbeda perlu menjalin hubungan yang erat dengan Indonesia dalam berbagai aspek, antara lain ekonomi.

\section{(Data 242/P7/0704/KM2)}

Pada penggalan wacana di atas terdapat konjungsi akibatan yang ditandai dengan kata karena itu mengacu pada konjungsi akibatan yang menyatakan akibat dari kalimat sebelumnya.

Dari sisi deklarasi harta dan uang tebusan bisa dikatakan cukup berhasil: tertinggi dibandingkan negara lain yang pernah menyelenggarakan program sejenis. Bahkan, angkanya melampaui ekspektasi banyak kalangan dan pemerintah.

(Data 237/P2/0104/KM1)

Pada penggalan wacana di atas terdapat konjungsi eksesif yang ditandai dengan kata bahkan mengacu pada konjungsi eksesif yang menyatakan akibat yang berlebihan tentang suatu hal yang telah disebut pada kalimat sebelumnya.

Komisi III DPR menekan KPK untuk menyerahkan bukti rekaman pemeriksaan Miryam. Karena pimpinan KPK menolak, sejumlah anggota Komisi III DPR mengancam akan menggunakan hak angket.

(Data 248/P5/2104/KM1)

Pada penggalan wacana di atas terdapat konjungsi sebaban yang ditandai dengan kata karena mengacu pada konjungsi sebaban yang bermakna sama dengan konjungsi akibatan, perbedaannya terletak pada konjungsi yang digunakan.

\section{Konjungsi Pertentangan}

Konjungsi yang digunakan sebagai pemarkah kohesi adalah akan tetapi, namun, dan tetapi. Dari 400 data terdapat konjungsi kontrastif yang ditandai dengan kata namun sebanyak 35 data, dan tetapi sebanyak 19 data. Sedangkan penunjuk ihwal yang ditandai dengan kata akan tetapi tidak ditemukan.

Harapannya, pemerintah tak menyianyiakan trust yang diberikan. Namun, kita tak menutup mata terhadap beberapa kelemahan dalam pelaksanaan program.

(Data 337/P6/0104/KM1)

Semula banyak yang berharap Pemerintah Persatuan Nasional yang menghidupkan kerja sama di antara berbagai blok politik di negeri itu memberikan harapan bagi segera terciptanya perdamaian. Tetapi, ternyata tidak.

(Data 378/P7/2504/KM2)

Pada penggalan wacana di atas terdapat konjungsi kontrastif yang ditandai dengan kata namun dan tetapi. Kata namun yang tercetak tebal pada data pertama mengacu pada konjungsi kontrastif yang menyatakan hubungan ketidaksesuaian apa yang disampaikan kalimat sebelumnya dan kata tetapi yang tercetak tebal pada data kedua mengacu pada konjungsi kontrastif yang menyatakan hubungan ketidaksesuaian apa yang disampaikan kalimat sebelumnya.

\section{Konjungsi Misalan}

Konjungsi yang digunakan untuk memarkahi hubungan kohesi adalah misal, misalnya, dan umpamanya. Dari 400 data terdapat konjungsi misalan yang ditandai dengan kata misalnya sebanyak 6 data. Sedangkan konjungsi misalan yang ditandai dengan kata misalnya dan umpamanya tidak ditemukan.

... Dengan memiliki senjata nuklir dan rudal, di bawah komando Kim Jong Un yang sulit ditebak, ancaman Korut bagi Korsel, Jepang, bahkan Amerika Serikat, terasa nyata dan bisa datang kapan saja.

Namun, menyerang lebih dulu, misalnya seperti yang dilakukan AS ke pangkalan udara Suriah, bukanlah pilihan bijak. Selain karena itu tak bisa dijamin memusnahkan seluruh rudal 
Korut, ancaman serangan balasan jauh lebih mengerikan. Jarak Seoul ke Pyongyang lebih dekat daripada Jakarta-Cirebon dan Jepang hanya terpisah laut di timur. Artileri dan rudal Korut dengan mudah menjangkau dan kehancuran yang ditimbulkan tak terelakkan.

(Data 399/P6/2704/KM2)

Pada penggalan wacana di atas terdapat konjungsi misalan yang ditandai dengan kata misalnya mengacu pada konjungsi misalan yang menyebutkan contoh-contoh tentang sesuatu hal yang telah disebutkan pada kalimat sebelumnya.

Fitur kebahasaan Tajuk Rencana Harian Suara Merdeka Edisi 1 sampai dengan 30 April 2017 dapat diketahui bahwa penggunaan pronomina penunjuk umum itu lebih sering muncul, yaitu sebanyak $12 \%$, penggunaan konjungsi kausalitas sebaban karena itu sebanyak $6,25 \%$, penggunaan konjungsi pertentangan namun sebanyak 17\%, dan konjungsi misalan misal sebanyak $0,75 \%$.

Fitur kebahasaan Tajuk Rencana Harian Kompas Edisi 1 sampai dengan 30 April 2017 dapat diketahui bahwa penggunaan pronomina penunjuk umum ini lebih sering muncul, yaitu sebanyak 9,75\%, penggunaan konjungsi kausalitas akibatan karena itu sebanyak 1,75\%, penggunaan konjungsi pertentangan namun sebanyak $8,75 \%$, dan konjungsi misalan misal sebanyak $1,5 \%$.

Berdasarkan hasil analisis dapat diketahui bahwa perbedaan karakteristik dari Tajuk Rencana Harian Suara Merdeka dan Kompas Edisi 1 sampai dengan 30 April 2017 adalah pada penggunaan fitur kebahasaan konjungsi pertentangan namun dalam Tajuk Rencana Harian Suara Merdeka Edisi 1 sampai dengan 30 April 2017 lebih banyak dari pada penggunaan jenis fitur kebahasaan yang lain, yaitu sebanyak $17 \%$; sedangkan penggunaan fitur kebahasaan peonomina penunjuk umum ini dalam Tajuk Rencana Harian Kompas Edisi 1 sampai dengan 30 April 2017 lebih banyak dari pada penggunaan jenis fitur kebahasaan yang lain, yaitu sebanyak 9,75\%.

\section{SIMPULAN}

Fitur kebahasaan yang terdapat dalam Tajuk Rencana Harian Suara Merdeka dan Kompas Edisi 1 sampai dengan 30 April 2017 sebagai berikut (1) fitur kebahasaan yang ditemukan dalam Tajuk Rencana Harian Suara Merdeka edisi 1 sampai dengan 30 April 2017 meliputi penggunaan pronomina penunjuk sebanyak 91 data, konjungsi kausalitas sebanyak 69 data, konjungsi pertentangan sebanyak 81 data, dan konjungsi misalan sebanyak 5 data; (2) Fitur kebahasaan yang ditemukan dalam Tajuk Rencana Harian Kompas edisi 1 sampai dengan 30 April 2017 meliputi, penggunaan pronomina penunjuk sebanyak 75 data, konjungsi kausalitas sebanyak 17 data, konjungsi pertentangan sebanyak 54 data, dan konjungsi misalan sebanyak 6 data; dan (3) berdasarkan persentase kedua tabel di atas dapat diketahui bahwa terdapat perbedaan karakteristik antara Tajuk Rencana Harian Suara Merdeka dan Kompas Edisi 1 sampai dengan 30 April 2017, yaitu; penggunaan fitur kebahasaan konjungsi pertentangan namun dalam Tajuk Rencana Harian Suara Merdeka Edisi 1 sampai dengan 30 April 2017 lebih banyak dari pada penggunaan jenis fitur kebahasaan yang lain, yaitu sebanyak $17 \%$, sedangkan penggunaan fitur kebahasaan peonomina penunjuk umum ini dalam Tajuk Rencana Harian Kompas Edisi 1 sampai dengan 30 April 2017 lebih banyak dari pada penggunaan jenis fitur kebahasaan yang lain, yaitu sebanyak $9,75 \%$.

\section{DAFTAR PUSTAKA}

Aji, Wasono N. E. (2017). Pandangan Harian Suara Merdeka dalam Konflik KPK vs Polri Jilid II: Analisis Wacana Kritis pada Tajuk Rencana. Jurnal Seloka Universitas Negeri Semarang.

Alwi, Hasan, dkk. (2003). Tata Bahasa Baku Bahasa Indonesia Edisi Ketiga. Jakarta: Balai Pustaka.

Anderson, Mark dan Kathy Anderson. (2003). Text Types in English.

Etikawati, Dina. (2015). "Kesantunan Tuturan Antartokoh dalam Novel Namaku Mata Hari Karya Remy Sylado". Jurnal Sastra Indonesia Universitas Negeri Semarang.

Faulin, Ahmad. (2018). Keefektifan Pembelajaran Menganalisis Struktur dan Kebahasaan Teks Eksposisi dengan Model Group Investigation 
dan Model Student Team Achievment Division (Stad) pada Siswa Kelas X SMK. Jurnal Pendidikan dan Satra Indonesia.

Hartono, Bambang. (2012). Dasar-Dasar Kajian Wacana. Semarang: Pustaka Zaman.

Kesuma, Tri Mastoyo Jati. 2007. Pengantar (Metode) Penelitian Bahasa. Yogyakarta: Carvitibooks.

Kosasih, E.. (2014). Jenis-Jenis Teks dalam Mata Pelajaran Bahasa Indonesia SMA/MA/SMK (Analisis Fungsi, Struktur, dan Kaidah serta Langkah-langkah Penulisannya). Bandung: Yrama Widya.

Kurniaji, Febrian. (2018). Pilihan Bahasa Anak Jalanan Penjual Koran di Kawasan Tugu Muda Semarang. Jurnal Sastra Indonesia Universitas Negeri Semarang.

Mahsun. (2014). Teks dalam Pembelajaran Bahasa Indonesia Kurikulum 2013. Jakarta: PT RajaGrafindo Persada.

Moleong, Lexy J. 2009. Metode Penelitian Kualitatif. Bandung: Remaja Rosdakarya.

Sudaryanto. (2015). Metode dan Aneka Teknik Analisis Bahasa. Pengantar Penelitian Wahana Kebudayaan Secara Linguistis. Yogyakarta: Sanata Dharma University Press. 